\title{
Morphological characterization of wheat genetic resources from the Island of Madeira, Portugal
}

\author{
Teresa M. M. dos Santos • Filipe Ganança • \\ Jan J. Slaski · Miguel Â. A. Pinheiro de Carvalho
}

Received: 4 February 2008/Accepted: 18 August 2008/Published online: 16 September 2008

(C) Springer Science+Business Media B.V. 2008

\begin{abstract}
This paper presents the first comprehensive morphological characterization and identification of the wheat populations collected on the Archipelago of Madeira and preserved at the ISOPlexis Germplasm Bank, the University of Madeira, Funchal. Fifty-two wheat populations representing Madeira's Triticum diversity and a wide range of ecological conditions were evaluated based on the biometrical and cytometrical traits. Forty-six traits related to plant morphology, cytological and grain characteristics were included in a multivariate analysis. Taxonomic identification of the collected materials revealed the presence of 3 species, 2 subspecies and 16 botanical varieties among the Madeiran wheat germplasm. The obtained results were confirmed by the multivariate analysis since all accessions were grouped in clusters corresponding also to different taxonomic levels. The detailed
\end{abstract}

T. M. M. dos Santos · F. Ganança •

J. J. Slaski - M. Â. A. Pinheiro de Carvalho ISOPlexis, Germplasm Bank, Centre for the Macaronesian Studies, University of Madeira, 9000-390 Funchal, Portugal

F. Ganança ( ( )

Centro de Estudos da Macaronésia, Universidade da Madeira, 9000-081 Funchal, Portugal

e-mail: jofitei@gmail.com

\section{J. J. Slaski}

Bioresource Technologies, Alberta Research Council, Vegreville, AB, Canada T9C 1T4 description of the Madeiran wheat landraces may contribute also to the protection of the existing Triticum diversity as well as support efforts of conservation of landraces, proper germplasm preservation and utilization.

Keywords Madeira $\cdot$ Morphological characterization - Taxonomic classification .

Triticum aestivum · Variety identification .

Wheat resources

\section{Introduction}

Cultivated Wheat emerged about 10,000 years ago in an area belonging now to north-western Iran or northeastern Turkey (McFadden and Sears 1946; Zohary and Hopf 2000). The first introductions of wheat in Europe occurred around $7000 \mathrm{BC}$ in the southern portion of the continent and from there the species migrated to North Africa (Feldman 2001), while a second major wave of migration occurred from North Africa during the middle Ages (Moragues et al. 2006a). The first introductions of wheat to the Archipelago of Madeira commenced in the 15th century from mainland Portugal along with the island colonisation when a great variety of crop species were brought here from different geographical regions of the world. Several later introductions have occurred in the 17th and 18th centuries from North 
Africa and Europe (Vieira 1983b). Since then, the Archipelago played an important role in the wheat exchanges and globalization of this crop (Ferrão 1992).

The Portuguese Archipelago of Madeira is located on the Atlantic Ocean, between the latitudes of $33^{\circ} 10-32^{\circ} 20 \mathrm{~N}$ and longitudes $16^{\circ} 10 \quad 17^{\circ} 20 \mathrm{~W}$, $630 \mathrm{~km}$ west of the coast of North Africa, and consists of five islands: Madeira, Porto Santo, Deserta Grande, Deserta Pequena and Bugio. The main islands are Madeira with an area of $728 \mathrm{sq} \mathrm{km}(50$ by $25 \mathrm{~km})$, and Porto Santo with an area of $50 \mathrm{~km}^{2}$. Madeira itself is the largest and highest of the islands, where Pico Ruivo (1861 m asl) and Pico de Areeiro (1820 $\mathrm{m}$ asl) are the highest peaks. The Archipelago is of volcanic origin, and shows specific soil and edaphic features, which have promoted the adaptation of wheat cultivars and evolution of local crop landraces (Pinheiro de Carvalho et al. 2003, 2004a). Although the Archipelago of Madeira possesses a relatively mild subtropical climate, substantial differences in mean annual temperature and precipitation associated primarily with the elevation above sea level are recorded. For example, air temperature ranges from 15 to $28^{\circ} \mathrm{C}$ in the costal city of Funchal while in the mountainous region of Pico de Areeiro they reach $6-12^{\circ} \mathrm{C}$. Similarly, annual precipitation varies from $541 \mathrm{~mm}$ in Lugar de Baixo (50 m asl) on the South Coast to $1314 \mathrm{~mm}$ in Santana (538 m asl) on the North Coast. The annual average atmospheric relative humidity varies between $70 \%$ on the South Coast (Funchal) and $85 \%$ on the North Coast (Santana). These climatic conditions have strong impacts on agricultural practices and they have affected the development of local cultivars.

Over the course of the last five centuries the Archipelago of Madeira has accumulated an extraordinary agricultural heritage, especially of wheat, which is the oldest agricultural crop on the island. Initially, during the Portuguese Geographic Discoveries, the rapid increase in wheat diversity was associated with the special attributes of the archipelago isolation and mild climate. Accordingly the archipelago was used to test and quarantine crops brought from various locations from around the world before introduction of the best performing genotypes to the Portuguese mainland or to other Portuguese possessions scattered on many continents (Mota unpublished data). Subsequent introductions of wheat diversity were associated with new settlers arriving to the island who brought a wide variety of germplasm from other locations. The introduced diversity was preserved for several centuries as a result of specific cultivation practices adopted by the Madeiran farmers. For centuries, wheat was cultivated on all the inhabited islands of the archipelago at altitudes ranging from $30 \mathrm{~m}$ (Caniço or Santana) to 600-800 m asl (Maloeira, Santa Cruz or Campanário). Local farmers who operated on small plots, often located in remote and isolated mountain valleys, have been using their own stocks of wheat seeds that were apparently introduced to the island centuries ago. Therefore, the introduced genotypes of wheat that originated from a wide range of agro-climatic conditions similar to subtropical and Mediterranean environments were preserved over generations.

Besides the anthropogenic interventions, specific agro-climatic conditions of the Archipelago have greatly contributed to the selection of particular genotypes, and ultimately to the evolution of local wheat landraces. This adaptation may have occurred as a result of the involvement of genes (and epigenetic phenomena, as well) controlling plant morphological features and the effectiveness of physiological mechanisms of biomass production (cf. also Moragues et al. 2006a, b).

In recent years, abandoning of the traditional unprofitable cultivation practices on the Archipelago resulted in a threat of extinction of the wheat diversity. To prevent this unique component of Madeiran biodiversity from vanishing there was an urgent need to collect, evaluate and characterize the local wheat genetic resources at the ISOPlexis gene bank (Pinheiro de Carvalho et al. 2003). The evaluation of the wheat resources and the identification of local wheat landraces is essential to preserve the genetic resources, as well as to promote their sustainable use, and eventually, to provide economical profits to the farmers. At the same time, the evaluation of the genetic variability focused on some morphological traits of economic interest could be useful for choosing the appropriate initial materials for crop improvement in breeding programmes. There is a universally recognized need to improve overall knowledge regarding wheat germplasm resources, especially of the landraces and primitive wheats (Croston and Williams 1991). 
Morphological characterization and evaluation of the diversity of wheat resources and landraces has been extensively studied around the world including the Panjsher valley in Afghanistan (Buerkert et al. 2006), European winter wheat landraces (Dotlacil et al. 2002) or Oman wheat landraces (Al-Maskri et al. 2003). Old studies of Portuguese wheat diversity conducted by Vasconcellos (1933a, 1943) provided characteristics of only one Madeiran wheat landrace named Funchal. More recently, Silva and Meneses (1984) performed the first evaluation of Madeiran wheats and identified 30 varieties. Unfortunately, in this study the morphological characterization and the description of varieties were missing.

\section{Material and methods}

Plant material

Fifty two wheat populations collected between 1997 and 2005 from farmer's plots showing a great variability of ecological parameters, including altitudes ranging from sea level to over $800 \mathrm{~m}$ asl (Table 1, Fig. 1), average precipitation from 541 to $1314 \mathrm{~mm}$ per year, relative humidity between $70 \%$ and $85 \%$, soil $\mathrm{pH}$ between 4.23 and 6.87 , and soil organic matter between $0.55 \%$ and $4.40 \%$ (Pinheiro de Carvalho et al. 2003, 2004a). The populations were morphologically analysed using quantitative and qualitative characters. Accessions from each population were collected, identified and preserved at the ISOPlexis germplasm bank for future studies and conservation proposes.

\section{Evaluation trials}

The selected accessions were sowed during the season of 2006 and 2007 in the experimental farm at the University of Madeira, Funchal, at the end of January or beginning of February and yielded during June/July. Wheat accessions were cultivated, according to traditional Madeiran farmers, succeeded after potatoes and the sowing rate was 450 viable seeds per $\mathrm{m}^{2}$. All entries were grown in randomised complete block designs with three replications. The experimental units were plots $(4 \times 4 \mathrm{~m})$, with a row spacing of $20 \mathrm{~cm}$. The plots were fertilised with $76 \mathrm{~kg} / \mathrm{ha} \mathrm{N}, 38 \mathrm{~kg} / \mathrm{ha} \mathrm{P}$ and $\mathrm{K}$ and weeds were controlled chemically. In each plot, data of 46 morphological traits were taken on 20 randomly selected competitive plants per plot. Seventeen of the evaluated features were related to plant morphology, 20 to the ear morphology, 8 to the grain morphology and 1 to the chromosome number. The parameters study including plant height/length $(\mathrm{PH})$, plant growth habit $(\mathrm{PGH})$, plant colour $(\mathrm{PC})$, presence of awns or scurs (AP), awns (or scurs) length at tip of ear (ALET), ear density (ED), ear length (EL), ear shape (ES), ear colour (EC), awns colour (AC), ear profile width (EPW), ear face width (EFW), spikelet's number per spike (SNS), hairiness of convex surface of apical rachis segment (HCSARS), sheath flag leaf glaucosity (SFLG), blade leaf glaucosity (BLG), neck glaucosity (NG), ear glaucosity (EG), glume colour (GC), glume size (GS), glume shape (GSh), glume opening (GO);), glume pubescence (GP), shoulder width of lower glume (SWLG), shoulder shape of lower glume (SSLG), beak length of lower glume (BLLG), beak shape of lower glume (BSLG), internal hair extent of lower glume (IHELG), glume dorsal keel (GDK), straw cross section (SCS), kernel number per spikelet (KNS), grain colour (GrC), grain shape (GrS), grain length $(\mathrm{GrL})$, grain width $(\mathrm{GrW})$, grain ridged $(\mathrm{GrR})$, grain/ endosperm texture (GrT), brush hair length and grain apex shape (BHL), germ area shape (GAS), karyotype $(\mathrm{K})$, thousand grain weigh $(\mathrm{GrWe})$, presence or absence of ligule $(\mathrm{Li})$, auricules $(\mathrm{Au})$, apex shape of leaf blade (ASLB), beak of terminal glume (BTG) and leaf pubescence (LP). From those, 13 characters were quantitative while 33 were qualitative. These characters were defined following the wheat descriptors published by Vasconcellos (1933a, b) and Gadea (1954) or recommended by the IPGRI (1985), Anonymous (2003).

Ex situ analyses (in the laboratory) were performed based on the measurement of seed and ear parameters of at least 20 plants randomly selected from each population.

\section{Karyological analysis}

Seeds were germinated in moist paper for 3-5 days. Root tips (1-2 cm long) were excised, treated for 22$26 \mathrm{~h}$ at $4^{\circ} \mathrm{C}$ in distilled water, fixed in Carnoy's fluid for at least $24 \mathrm{~h}$, and stained with $2 \%$ acetocarmine. The apical 2-mm portion was removed and placed in 
Table 1 Characterization of wheat genetic resources from the Island Madeira

\begin{tabular}{|c|c|c|c|c|}
\hline $\begin{array}{l}\text { Population, } \\
\text { no. }\end{array}$ & Vernacular name & Varieties & Geographical origin & $\begin{array}{l}\text { Altitude } \\
(\mathrm{m})\end{array}$ \\
\hline 1 & TRIGO BRANCO & $\begin{array}{l}\text { melanatherum Körn. (nemausense } \\
\text { Wittm.) }\end{array}$ & SANTA CRUZ & 263 \\
\hline 2 & TRIGO BRANCO & milturum (Alef.) Mansf. & SANTANA & 491.5 \\
\hline 3 & TRIGO GALHOTO & milturum (Alef.) Mansf. & SANTANA & 388.5 \\
\hline 4 & TRIGO RAPOSO & milturum (Alef.) Mansf. & PONTA DE SOL & 663 \\
\hline 5 & TRIGO DA SERRA & erythrospermum (Körn.) Mansf. & PORTO MONIZ & 544 \\
\hline 6 & TRIGO VERMELHO & alexandrinum (Körn.) Perciv. & RIBEIRA BRAVA & 348 \\
\hline 7 & TRIGO CABEIRO & lutescens (Alef.) Mansf. & PORTO MONIZ & 362 \\
\hline 8 & TRIGO PRETO & milturum (Alef.) Mansf. & CALHETA & 614 \\
\hline 9 & TRIGO VERMELHO & niloticum Körn. & $\begin{array}{l}\text { CÂMARA DE } \\
\text { LOBOS }\end{array}$ & 407.5 \\
\hline 10 & TRIGO BARBELA & ferrugineum (Alef.) Mansf. & SANTANA & 510.5 \\
\hline 11 & TRIGO PARDO & creticum (Mazz.) Mansf. & SANTANA & 228.5 \\
\hline 12 & TRIGO LEACOCK & graecum (Körn.) Mansf. & SANTANA & 228.5 \\
\hline 13 & TRIGO LEACOCK & erythrospermum (Körn.) Mansf. & SANTA CRUZ & 263 \\
\hline 14 & TRIGO RAPOSO & milturum (Alef.) Mansf. & PONTA DE SOL & 500 \\
\hline 15 & TRIGO BRANCO & milturum (Alef.) Mansf. & SANTANA & 35.5 \\
\hline 16 & TRIGO CANALHA & milturum (Alef.) Mansf. & SANTANA & 471.5 \\
\hline 17 & TRIGO DOURADINHO & lutescens (Alef.) Mansf. & SANTANA & 262 \\
\hline 18 & TRIGO PRETO & libycum Körn. & PONTA DE SOL & 474.5 \\
\hline 19 & TRIGO S/PREGANA & milturum (Alef.) Mansf. & CALHETA & 629 \\
\hline 20 & TRIGO PELADINHO & lutescens (Alef.) Mansf. & CALHETA & 461 \\
\hline 21 & $\begin{array}{l}\text { TRIGO RUSSO DA } \\
\text { MALOEIRA }\end{array}$ & martensii Körn. & CALHETA & 594 \\
\hline 22 & TRIGO MOURO & icterinum (Alef.) Mansf. & PONTA DE SOL & 663 \\
\hline 23 & TRIGO BRANCO & milturum (Alef.) Mansf. & PORTO MONIZ & 553 \\
\hline 24 & TRIGO CANA ROXA & milturum (Alef.) Mansf. & SANTANA & 425,5 \\
\hline 25 & TRIGO BRANCO & milturum (Alef.) Mansf. & SANTANA & 261 \\
\hline 26 & TRIGO TEMPORÃO & graecum (Körn.) Mansf. & RIBEIRA BRAVA & 458 \\
\hline 27 & TRIGO ARROZ & lutescens (Alef.) Mansf. & SANTANA & 204 \\
\hline 28 & TRIGO RAPADINHO & creticum (Mazz.) Mansf. & SANTA CRUZ & 662.5 \\
\hline 29 & TRIGO GALHOTO & milturum (Alef.) Mansf. & SANTANA & 388.5 \\
\hline 30 & TRIGO DOIRADINHO & milturum (Alef.) Mansf. & SANTANA & 477 \\
\hline 31 & TRIGO RAPADO (BRANCO) & lutescens (Alef.) Mansf. & RIBEIRA BRAVA & 389.5 \\
\hline 32 & TRIGO RAPADINHO & milturum (Alef.) Mansf. & RIBEIRA BRAVA & 348.5 \\
\hline 33 & TRIGO RAPADO & milturum (Alef.) Mansf. & RIBEIRA BRAVA & 494.5 \\
\hline 34 & TRIGO RAPADO & lutescens (Alef.) Mansf. & RIBEIRA BRAVA & 372 \\
\hline 35 & TRIGO RAPADINHO & wernerianum (Körn.) Mansf. & RIBEIRA BRAVA & 795 \\
\hline 36 & TRIGO RAPOSINHO & icterinum (Alef.) Mansf. & PORTO MONIZ & 379 \\
\hline 37 & TRIGO RAPOSO & milturum (Alef.) Mansf. & MACHICO & 125 \\
\hline 38 & TRIGO VERMELHO & niloticum Körn. & RIBEIRA BRAVA & 795 \\
\hline 39 & TRIGO ROCHA (VERMELHO) & alexandrinum (Körn.) Percival & RIBEIRA BRAVA & 465.5 \\
\hline 40 & TRIGO MAÇAROQUINHO & icterinum (Alef.) Mansf. & PONTA DE SOL & 542 \\
\hline 41 & TRIGO DO CEDO & lutescens (Alef.) Mansf. & MACHICO & 253.5 \\
\hline
\end{tabular}


Table 1 continued

\begin{tabular}{|c|c|c|c|c|}
\hline $\begin{array}{l}\text { Population, } \\
\text { no. }\end{array}$ & Vernacular name & Varieties & Geographical origin & $\begin{array}{l}\text { Altitude } \\
\text { (m) }\end{array}$ \\
\hline 42 & TRIGO RAPADO BRANCO & milturum (Alef.) Mansf. & CALHETA & 490 \\
\hline 43 & TRIGO BRANCO & affine Körn. & SANTA CRUZ & 465 \\
\hline 44 & TRIGO NOVO & ferrugineum (Alef.) Mansf. & SANTA CRUZ & 801.5 \\
\hline 45 & TRIGO 3 MESES TEMPORÃO & graecum (Körn.) Mansf. & RIBEIRA BRAVA & 360.5 \\
\hline 46 & TRIGO CANA ROXA & milturum (Alef.) Mansf. & SANTANA & 280 \\
\hline 47 & TRIGO BRANCO & nigrobarbatum Desv. & CALHETA & 561 \\
\hline 48 & TRIGO LARGO EM CIMA & milturum (Alef.) Mansf. & CALHETA & 536.5 \\
\hline 49 & TRIGO MENTANA & graecum (Körn.) Mansf. & CALHETA & 491 \\
\hline 50 & TRIGO GALHOTO & lutescens (Alef.) Mansf. & SANTANA & 411 \\
\hline 51 & TRIGO AMARELO & obscurum Körn. & RIBEIRA BRAVA & 533.5 \\
\hline 52 & TRIGO LEACOCK & erythrospermum (Körn.) Mansf. & RIBEIRA BRAVA & 520 \\
\hline
\end{tabular}

Vernacular name, botanical varieties, place of origin and plot altitude of Madeiran wheat populations considered in this study

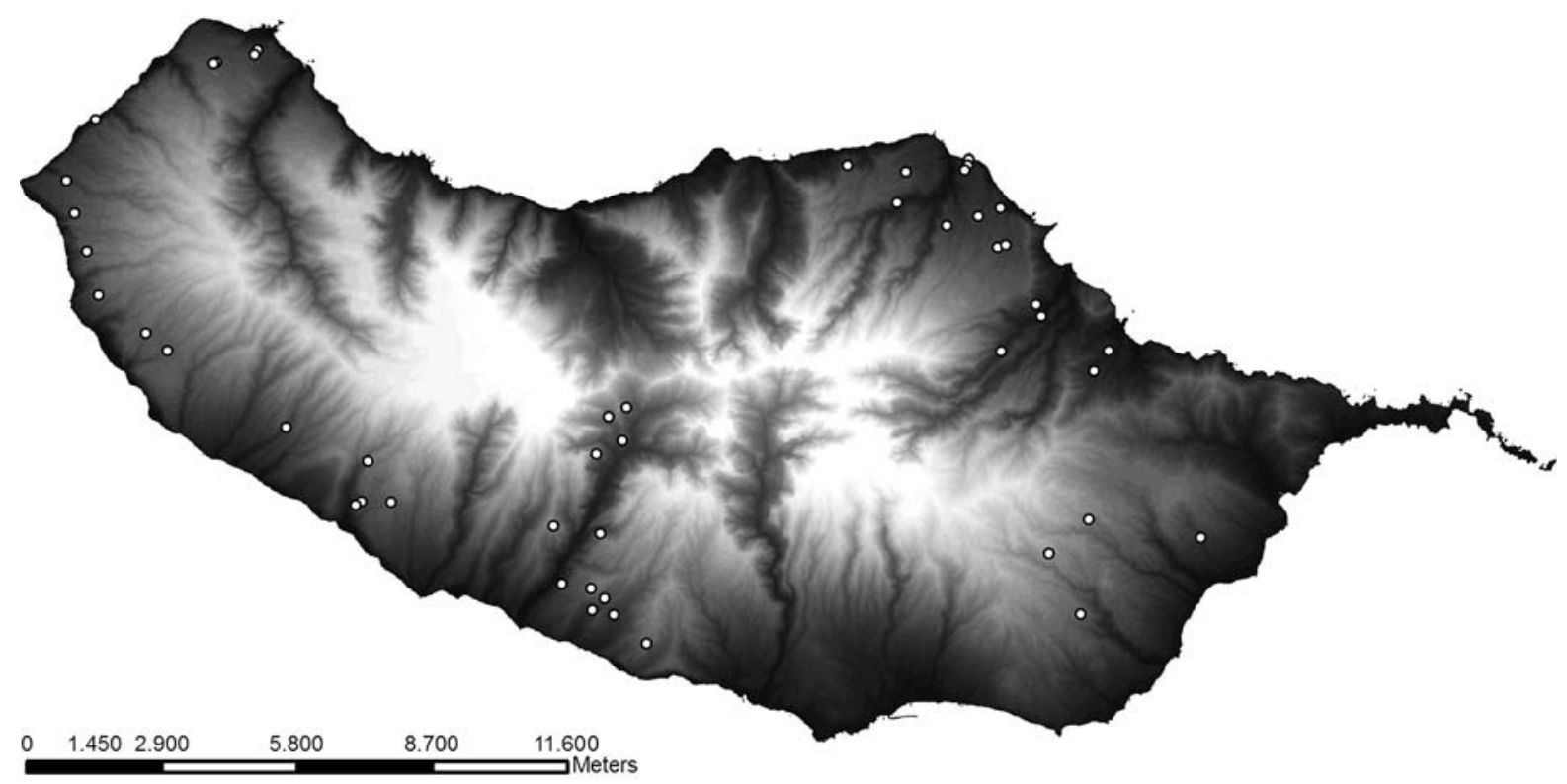

Fig. 1 Collections sites of the 52 wheat populations on the Island of Madeira

a drop of $45 \%$ acetic acid. Permanent squash preparations for studying chromosome number (Karyotype) were made in a standard manner. The slides were scanned and photographs at $400 \times$ magnification.

\section{Taxonomical identification}

The morphological data were used to identify the species, sub-species and botanical varieties. Taxonomical classifications were performed according to
Vasconcellos (1933a, b, 1943), Gadea (1954), Mansfeld (1951) and Dorofeev et al. (1979).

Multivariate analysis

The multivariate analysis is a powerful tool frequently used to evaluate the morphological variability of different crop species and to identify groups of accessions that possess traits desirable for breeding programmes, creation of core collections, and to detect the patterns of variation in 
germplasm collections (Pinheiro de Carvalho et al. 2004b, 2008).

The morphological quantitative and qualitative data were used in multivariate analysis with the major goals to measure the observed diversity, to confirm the results of the taxonomical identification and to determine the main characters that allow differentiation between the varieties. The Principal Components Analysis (PCA) and the Principal Coordinates Analysis (PCO) were used for analysis of the morphological traits. The Gower general similarity coefficient's that summarised variation and discriminated the weight of qualitative characters was generated using the MVSP for Windows following Kovach (1999). The discrimination analysis was performed to verify the accuracy of the classification of the examined populations using the program SPSS for Windons version 11 (Kinnear and Gray 1999).

\section{Results}

The present study reports results of in situ and ex situ biometrical observations and measurements conducted between 2006 and 2007 on fifty two wheat populations collected from small farmer's plots on the largest island of the Archipelago of Madeira. Although collection sites were scattered across the island at elevations ranging from 35.5 to $801 \mathrm{~m}$ asl, the majority $(85 \%)$ of the population was collected from plots located at elevations between 200 and $600 \mathrm{~m}$ asl (Fig. 1, Table 1). Using the taxonomical systems of Mansfeld (1951), Dorofeev et al. (1979) three species, Triticum aestivum L., Triticum turgidum L., Triticum. durum Desf. and 2 subspecies, T. aestivum and T. aestivum subsp. compactum (Host) Mac Key have been identified among the collected wheat populations (Table 2). T. aestivum L. and T. turgidum L. were differentiated based on the K, EL, LP, SCS, GB, GrL, GDK, AC characters and characters of the spikelets following the taxonomical classification of Vasconcellos (1933a, b) and Gadea (1954).

PCA analysis revealed that wheat accessions were clustered in two main groups with a clear discontinuity (Fig. 2a). The separation along both PCA axes explained $33.07 \%$ of variation. PH, AP, ALET, ED, GC, GO, Au, EPW, SCS, SNS, EL, ES, GrL, GrS, GrW, GrT, K, LP, ASLB, GDK, BHL and GAS contributed to the separation of accessions along the PCA axis 1 (17.56\% of variation), while the characters AP, EL, EPW, GS, GS, GDK, BLLG, SNS, GrL, GrW, GrC, PC, ASLB, LP, HCSARS and K contributed to the separation along axis $3(7.20 \%$ of variation) (Fig. 2a).

Contribution of the second and the fourth axes to the distribution of wheat accessions was less
Table 2 Taxonomic identification of wheat species, subspecies and taxonomic varieties detected among 52 wheat populations from the Island of Madeira

The taxonomic identification has performed according to Mansfeld (1951), Vasconcellos (1933a, b) and Gadea (1954)

\begin{tabular}{|c|c|c|}
\hline Species & Varieties & $\begin{array}{l}\text { Number of } \\
\text { populations }\end{array}$ \\
\hline T. aestivum $\mathrm{L}$. & milturum (Alef.) Mansf. & 19 \\
\hline T. aestivum $\mathrm{L}$. & lutescens (Alef.) Mansf. & 8 \\
\hline T. aestivum $\mathrm{L}$. & erythrospermum (Körn.) Mansf. & 3 \\
\hline T. aestivum $\mathrm{L}$. & ferrugineum (Alef.) Mansf. & 2 \\
\hline T. aestivum $\mathrm{L}$. & graecum (Körn.) Mansf. & 4 \\
\hline T. aestivum $\mathrm{L}$. & creticum (Mazz.) Mansf. & 2 \\
\hline T. aestivum $\mathrm{L}$. & icterinum (Alef.) Mansf. & 3 \\
\hline T. aestivum $\mathrm{L}$. & wernerianum (Körn.) Mansf. & 1 \\
\hline T. durum Desf. & alexandrinum (Körn.) Perciv. & 2 \\
\hline T. durum Desf. & affine Körn. & 1 \\
\hline T. durum Desf. & melanatherum Körn. (nemausense Wittm.) & 1 \\
\hline T. durum Desf. & niloticum Körn. & 2 \\
\hline T. durum Desf. & libycum Körn. & 1 \\
\hline T. durum Desf. & obscurum Körn. & 1 \\
\hline T. turgidum $\mathrm{L}$. & martensii Körn. & 1 \\
\hline T. turgidum $\mathrm{L}$. & nigrobarbatum Desv. & 1 \\
\hline
\end{tabular}


Fig. 2 (a) The Principal Coordinates Analysis of 52 wheat populations from Madeira Separation along both PCA axes explains $33.07 \%$ of the variation, axis 1 and 3 explain $17.56 \%$ and $7.20 \%$ of variation, respectively; Cumulative Eigen-values 13.89. (b) The Principal Coordinates Ordination of 52 wheat populations from Madeira Analysis explains $24.0 \%$ of the observed field variability. Cumulative Eigen-values 13.89

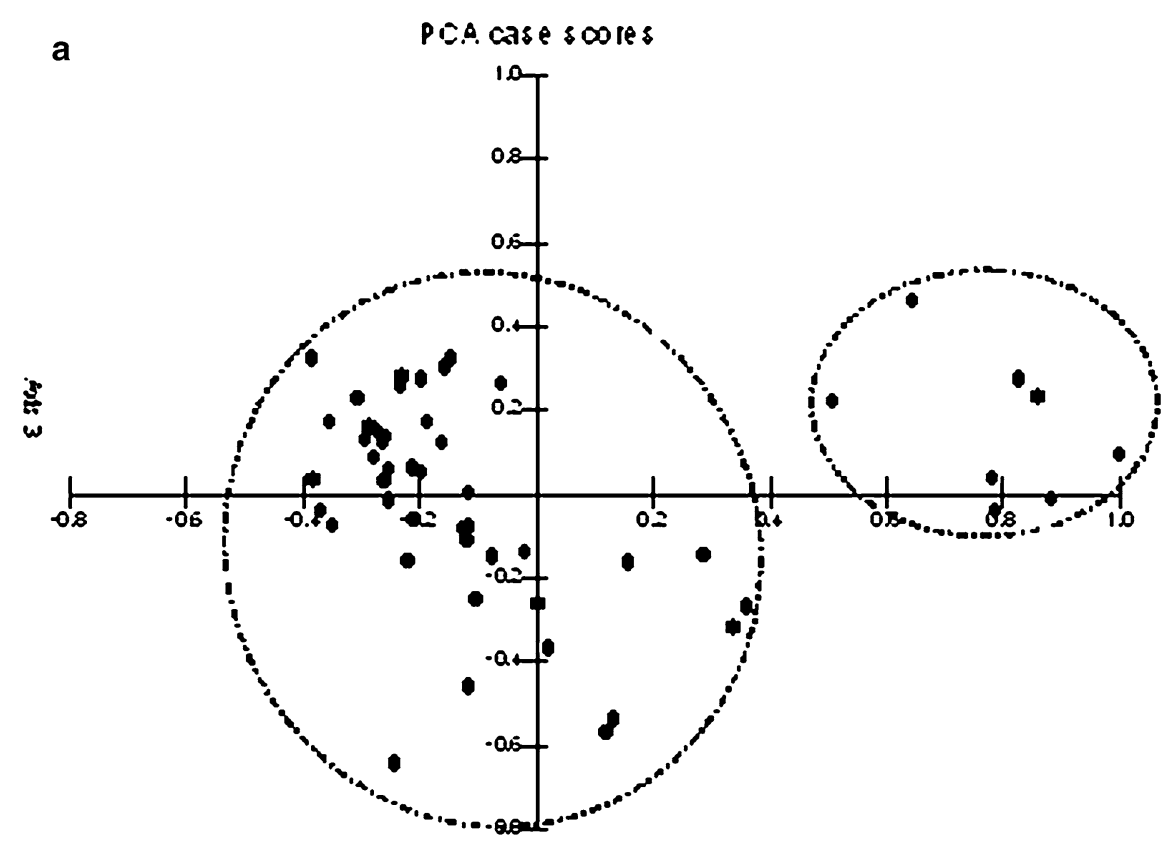

.2x: 1

b PCO case scores (Gower General Simila rity Coefficient)

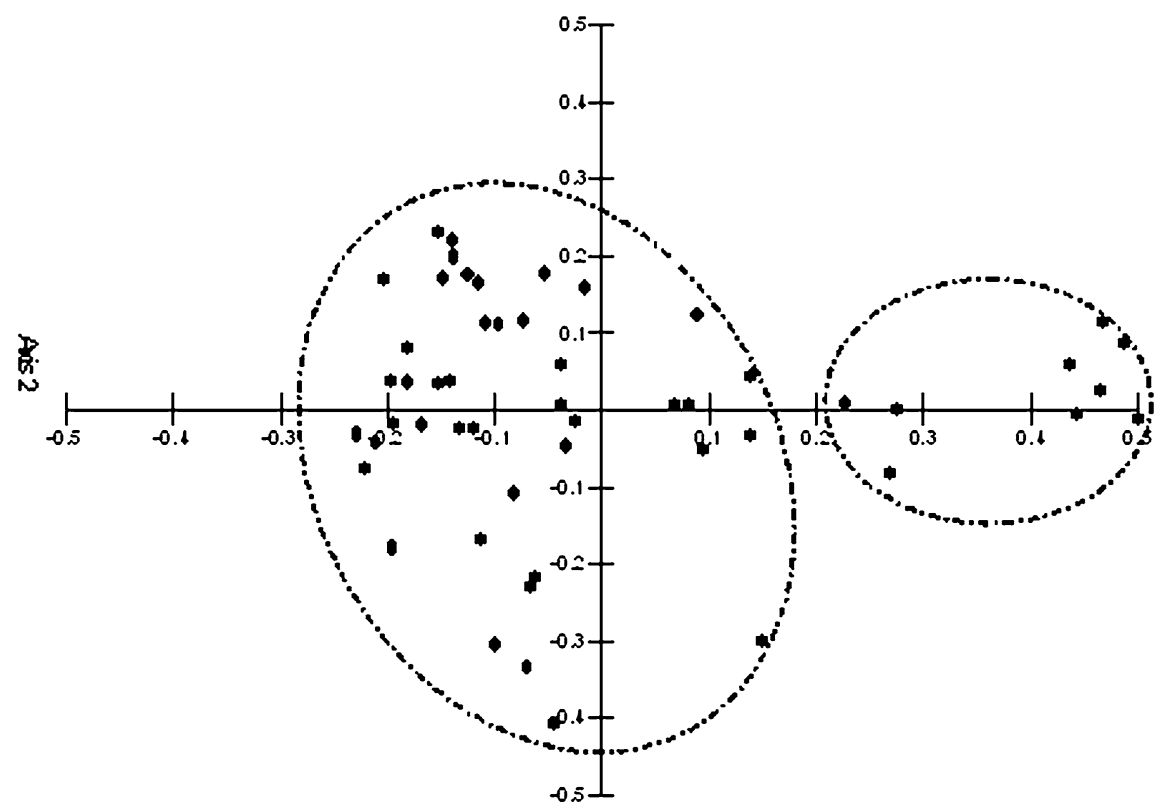

A.xis 1 profound, and the latter one explained only $6.70 \%$ variation. The sum of Eigen-values for axes 1 and 3 was 13.89 from the total value of 32.91 . The PCO analysis using the Gower general similarity coefficient also confirmed the discontinuity of variability in wheat populations detected by the PCA analysis, clustering all accessions into two groups (Fig. 2b). The separation along both PCO axes explained $24.0 \%$ of variation. The sum of Eigen-values for both axes was 3.80 of the total value of 10.95 . The third axis that explained only $5.81 \%$ did not enhance separation of the accessions. 
One group detected using the PCA and PCO analyses included $T$. aestivum $\mathrm{L}$. and the other the durum wheat, what was consistent with the performed taxonomic classification at the specific level (Table 2). Forty-two of the studied populations were classified as Triticum aestivum L.; while 2 populations belong to T. turgidum L. and 8 to T. durum Desf. All populations classified as T. aestivum L. were divided into two subspecies based on the ED, EL, SCS, PH, and awns, spikelet and grain traits (Vasconcellos 1933a; Gadea 1954). These subspecies included Triticum aestivum L. and T. aestivum subsp. compactum (Host) Mac Key. To validate this taxonomic classification the PCA and PCO analyses were performed using the Gower general similarity coefficients (Fig. 3a, b). Both approaches revealed that wheat accessions were clustered in two main groups with a clear discontinuity and these two groups were consistent with the previously made taxonomic identification (Table 2). Separation along the both PCA axes explained $22.50 \%$ of variation (Fig. 3a). AP, ALET, GS, GDK, BLLG, SNS, EL, GrL, GrW, GrC, GrT, (GrWe), PC, PGH, ASLB, BTG and CSHARS contributed a higher weight to the separation of accessions along the PCA axis 1 (variation of $11.48 \%$ ), while the characters AP, ALET, GC, GO, SNS, KNS, ES, EL, EPW, GrL, GrW, PGH, GrWe, PC, GDK, BHL, GAS and CSHARS contributed to the separation along the PCA axis 2 (variation of $11.01 \%$ ). The sum of Eigen-values for both axes was 9.22 from of the total value of 33.51. The third axis was not taken into consideration as it explained only $8.11 \%$ and it did not contribute to a better spatial separation of accessions. The separation along two PCO axes explained $19.44 \%$ of variation, and the sum of Eigen-values for both axes was 2.42 from of the total value of 9.18 (Fig. 3b). Thirty six of the wheat populations belong to Triticum aestivum L., while 6 wheat cultivars were classified as T. aestivum subsp. compactum (Host) Mac Key (Table 2).

Based on the ED, GDK, LP, PH, and awns and grain characters (Vasconcellos 1933a; Gadea 1954) two species including Triticum durum Desf. and $T$. turgidum L. were also identified in wheat populations classified as T. turgidum L. As in the previous cases, verification of the taxonomical classification was conducted using the PCA and PCO analyses. The PCO analysis is an effective tool for explaining the observed taxonomical diversity (Fig. 4a, b). The separation along both PCA axes explained $39.32 \%$ of variation (Fig. 4a). The characters PL, PC, ED, GC, GDK, BLLG, SCS, EL, EFW, GrL, GrW, BHL, K, LP, ASLB, Au, Li, GrS and GrR predominantly contributed to the separation of accessions along the PCA axis 1 (21.02\% of variation), while the characters AP, ALET, GDK, EFW, EPW, GrL, GrW, K, PL, PC, LP, ASLB, BTG, GDK, GP, GrS, BHL, GAS and GrR contributed to the separation along the PCA axis 2 (18.30\% of variation). The sum of Eigen-values for both axes was 16.12 from the total value of 41.00 . The separation along two PCO axes explained $36.55 \%$ of variation, while the sum of Eigen-values for both axes was 1.21 from the total value of 3.30 (Fig. 4b). Eight of the analysed cultivars were identified as T. durum Desf., while two cultivars belong to T. turgidum L. (Table 2).

Dichotomic keys have been used to classify wheat genetic resources within each taxonomical subspecific unit using as outgroups for this classification the Vasconcellos classification and botanical varieties (Vasconcellos 1933a, b). This approach resulted in the identification of 16 botanical varieties among the wheat populations (Table 2). Only three characters separated these varieties. Triticum aestivum L. represented by 5 out of 16 botanical varieties was identified as the largest group, belonging mostly to varieties milturum (Alef.) Mansf. and lutescens (Alef.) Mansf.

Triticum aestivum subsp. compactum (Host) Mac Key was represented by 3 botanical varieties, while var. icterinum Körn. was the most widespread.

T. durum Desf. was represented by 6 botanical varieties, according to the Vasconcellos (1933a), Flaksburger (1935, 1939) and Mansfeld (1951) classification: var. alexandrinum (Körn.) Percival and var. libycum Körn. were the most representative for this group. Finally, Triticum turgidum L. was represented by 2 botanical varieties, nigrobarbatum Desv. and martensii Körn. In total 16 botanical varieties and 29 cultivars (data not shown) have been identified.

\section{Discussion}

Wheat is the oldest agricultural crop introduced to the Archipelago of Madeira over 500 years ago. Subsequent multiple introductions of wheat originating 
Fig. 3 (a) The Principal Coordinates Analysis of Triticum aestivum $\mathrm{L}$. populations from Madeira Analysis explains $22.5 \%$ of the observed field variability. Axis 1 explains $11.48 \%$ and Axis 2 explains $11.01 \%$ of variability. The sum of Eigen-values for both axes is 9.22 from the total value of 33.51. (b) The Principal Coordinates Ordination of Triticum aestivum L. from Madeira Analysis explains $19.44 \%$ of observed field variability. The sum of Eigen-values for both axes is 2.42 from the total value of 9.18
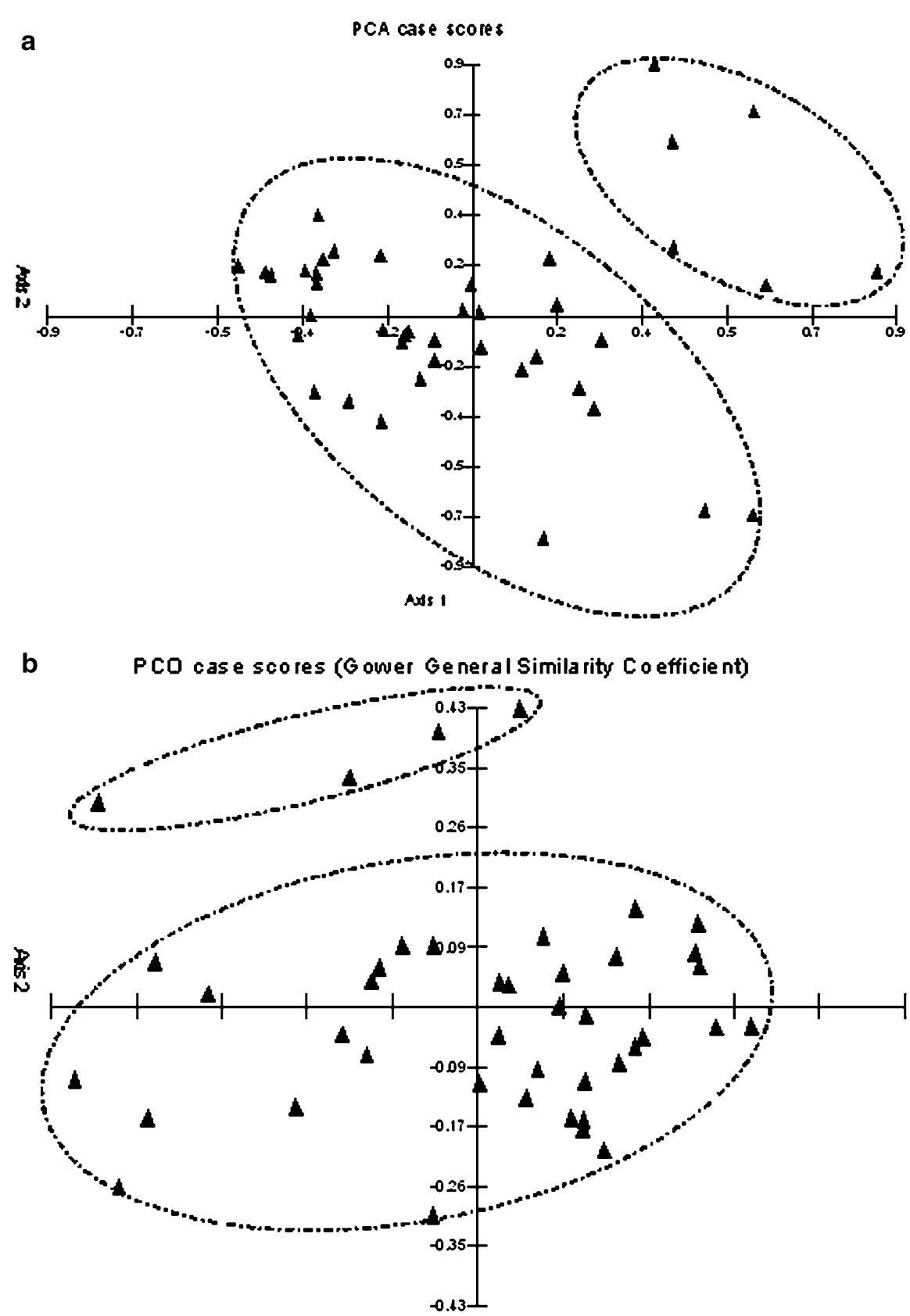

Axis 1 from numerous locations around the world, combined with local cultivation practices led to the preservation of the gene pool over generations, and resulted in an accumulation of wheat diversity over time.

Monitoring of wheat diversity on Madeira revealed that all accessions belonged to the bread or durum wheat. However, the bread wheat prevails among the Madeiran wheats accounting for $81 \%$ of all populations studied in the present work. The high morphological variability observed across the crop populations reflecting the predominance of bread wheat (T. aestivum L.) among local landraces could result from farmer's preference for bread. However, the durum wheat (T. turgidum L.), well adapted to local environmental conditions is maintained to make traditional bread (pure or mixed with bread wheat 
Fig. 4 (a) The Principal Coordinates Analysis of Triticum turgidum L. populations from Madeira. Analysis explains $39.32 \%$ of the observed field variability. Axis 1 explains $21.02 \%$ and Axis 2 explains $18.30 \%$ of variability. The sum of Eigen-values for both axes is 16.12 from the total value of 41.00 . (b) The Principal Coordinates Ordination of Triticum turgidum L. populations from Madeira. Analysis explains $36.55 \%$ of the observed field variability. The sum of Eigen-values for both axes is 1.21 from the total value of 3.30

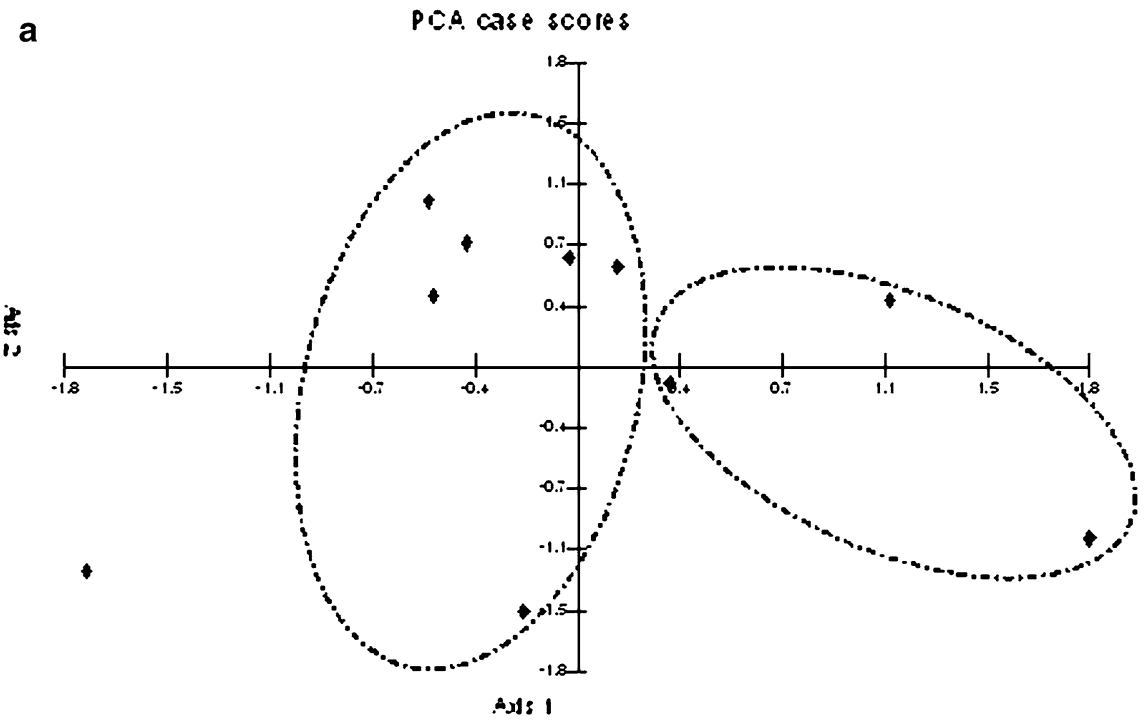

b PCO case scores (Gower General Similarity Coefficient)

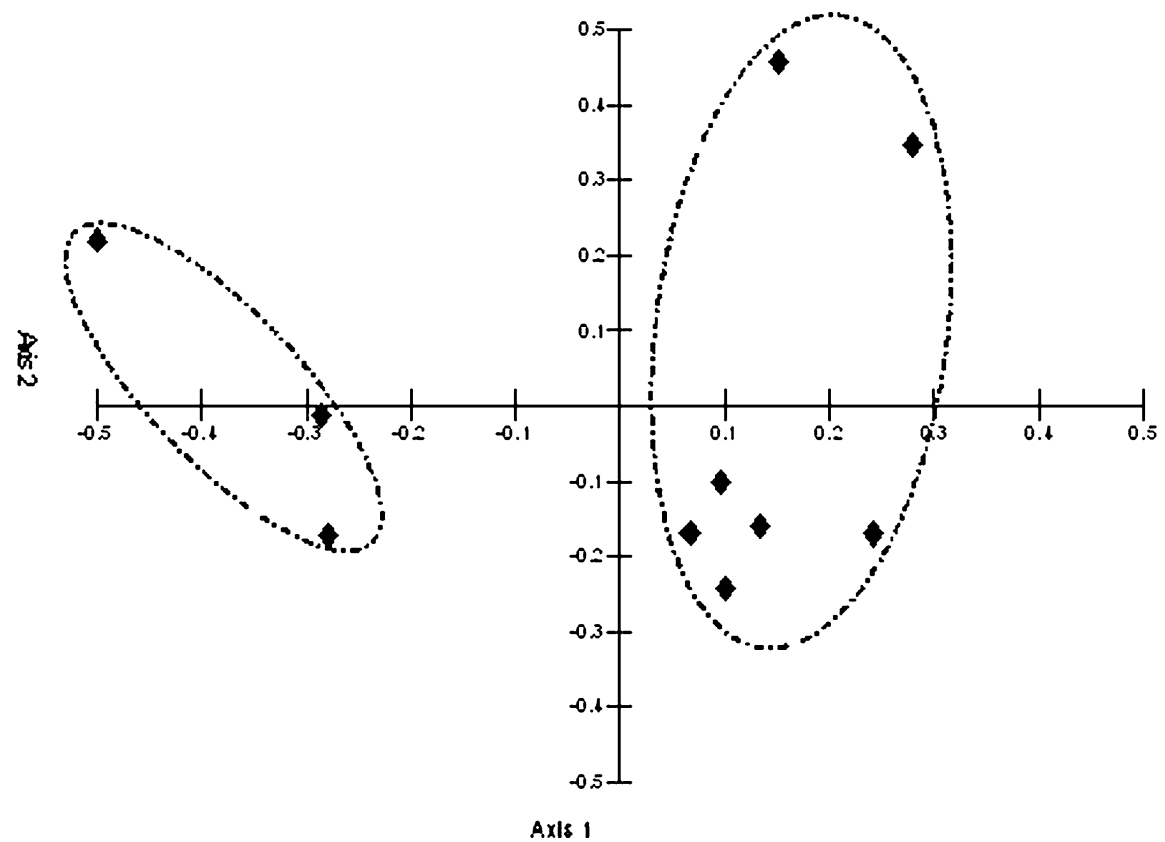

flour), to prepare soups, or use it for production of traditional ornaments for Christmas festivities. Since the range of applications for T. turgidum is restricted to few traditional uses, the need for the seeds is also limited.

Classification of the Madeiran wheat genetic resources reported in the present paper differs from the earlier work performed by Silva and Meneses (1984). We have identified only 7 out of 30 varieties or cultivars previously reported. The identification of
16 botanical varieties and 29 cultivars (data not shown) suggests that wheat genetic heritage on Madeira was underestimated by Silva and Meneses (1984). The reason for the discrepancy could be also lack of knowledge: previous classification was only based on visual comparisons and it did not involve any in-depth morphological studies on population samples evaluated on experimental fields. Because of the poor methodology used two decades ago it is impossible to assess the magnitude of the loss of 
wheat biodiversity on the island. The loss of wheat diversity was, e.g., show in Italian wheats using also the decrease of botanical varieties over the years (Hammer and Laghetti 2005).

Two major factors contributed to the present diversity of wheat on Madeira. First, successive introductions of new cultivars from different parts of Europe and North of Africa (Vieira 1983a, b), and second, selection and adaptation to specific agroecological conditions and practices.

On Madeira, wheat is cultivated almost always without the input of mineral fertilizers, while organic fertilizers, typically in the form of postharvest residues of other crops used in rotation (corn, beans), are the only source of nutrients for wheat. Different rotational and cultivation practices used by farmers in different parts of the archipelago might have contributed to the development of wheat landraces well adapted to local conditions. It has been demonstrated that geographical isolation of wheat at locations characterized by different environmental conditions acted as a source of crop diversification in relatively short time periods (Zeven 1998; Börner et al. 2005; Bardsley and Thomas 2005). We hypothesize that the diversity of edapho-ecological conditions and agricultural practices present on Madeira promoted the development of the local wheat landraces. These landraces need to be identified and evaluated in relation to their most attractive agronomical traits.

A broad-sense heritability of several morphological and agronomic traits independently of ecological conditions that has been recently reported by Ferrio et al. (2006) and was also observed in Madeiran wheat variability.

Multivariate and discrimination analyses permitted weighting the morphological variability of bread and durum wheats (Figs. 2-4) $98.1 \%$ populations were correctly classified and identified. Discrimination between the species has been preformed using three major characters (GrL, ED and $\mathrm{K}$ ).

All observed variability can be explained by the existence of three species groups (Fig. 2a, b).

As far as the diversity within the T. aestivum L. all accessions were traditionally classified. GrL, ED and SNS predominantly contributed to the distinction between species. We were able to classify $90 \%$ of $T$. turgidum $\mathrm{L}$. accessions and distinction between the species' was possible using the PL and GrL traits. Several genes are responsible for the controlling these traits. It has been documented that reproductive traits are not really influenced by the environment (Ferrio et al. 2006). Vasconcellos (1933a) and Gadea (1954) described several landraces and varieties from Portugal and Spain using a similar approach based on the morphological characterization The authors identified valuable sources of germplasm for breeding and improvement of wheat among the studied populations and they have contributed to the evaluation and characterization of the wheat germplasm in both countries. Vasconcellos (1933a), Flaksberger (1939) and Gadea (1954) all accepted the highest taxonomic value of plant, ear and grain traits.

Thorough morphological characterization of the Madeiran wheat resources provides several evidences regarding their different geographical origin. It has been long recognized that awns can substantially increase spike photosynthesis and subsequently yields under dry conditions (Bremner and Rawson 1972; Olugbemi et al. 1976; Atkins and Norris 1955). Our data showed that the awned varieties including graecum Körn., erythrospermum Körn., ferrugineum (Alef.) Mansf., icterinum Körn., alexandrinum Körn., affine Körn., melanatherum Körn. (nemausense Wittm.), niloticum Körn., libycum Körn., obscurum Körn., martensii Körn., nigrobarbatum Desv. are predominant on the island. High levels of sun radiation and a high average annual temperature could perhaps resemble conditions similar to the place of origin of wheats. However, high levels of atmospheric humidity on Madeira and ample precipitation would possibly favour the development of awnedness landraces. Therefore, we incline to claim that predominance of awned varieties on the island could be only explained by the initial place of provenance of these wheats (Vieira 1983a, b; Börner et al. 2005).

The majority of Madeira wheat populations studied in the present work belongs to the variety group milturum Alef., grouping varieties with good adaptation to the Madeiran conditions.

It has been also postulated that cultivars growing in regions receiving high light intensity have a tendency to develop coloured spikes (Flaksburger 1935). Again, predominance of varieties with coloured spikes on Madeira, belonging to T. aestivum var: ferrugineum (Alef.) Mansf., milturum (Alef.) Mansf., creticum (Mazz.) Mansf., T. durum var: niloticum Körn., libycum Körn., obscurum Körn., 
T. turgidum var. $\times$ martensii Körn. and nigrobarbatum Desv. most likely indicates that these varieties originated from subtropical regions.

The appearance of glumes could be also used to predict cold tolerance of wheat cultivars, hence indirectly could allude to the area of origin. For example, Trethowan et al. (1998) suggested that glabrous glumes prevail in the warmer regions, while pubescent forms are more frequently spotted in region experiencing low temperatures. The glabrous nature of glumes found in majority of the Madeiran wheats could be perhaps another indication of their origin from mild climates having an annual average temperature around $20^{\circ} \mathrm{C}$, with cold temperatures occuring only in the beginning of the growing season.

In conclusion, the morphological evaluation of the Madeiran wheat germplasm reported herein revealed a considerable genetic diversity, a rich source of genes for crop improvement programmes.

Acknowledgements Portuguese Foundation for the Science and Technology (FCT, Fundação para a Ciência e Tecnologia) and the European Community have sponsored this work, through the Centre of Macaronesian Studies (CEM) and the projects POCTI no. 35003/AGR/2001 and INTERREG IIIB, Germobanco. The authors are grateful to the Madeiran farmers who assisted with collection of wheat samples.

\section{References}

Al-Maskri A, Nagieb M, Hammer K, Filatenko AA, Khan I, Buerkert A (2003) A note about Triticum in Oman. Genet Resour Crop Evol 50:83-87

Anonymous (2003) Protocol for distinctness, uniformity and stability tests. Wheat. European Union, Community Plant Variety Office

Atkins IM, Norris MJ (1955) The influence of awns on yield and certain morphological characters of wheat. Agron $\mathrm{J}$ 47:218-220

Bardsley D, Thomas I (2005) Valuing local wheat landraces for agrobiodiversity conservation in Northeast Turkey. Agric Ecosyst Environ 106:407-412

Börner A, Schäfer M, Schmidt A, Grau M, Vorwald J (2005) Associations between geographical origin and morphological characters in bread wheat (Triticum aestivum L.). Plant Genet Resour 3(3):360-372

Bremner PM, Rawson HM (1972) Fixation of ${ }^{14} \mathrm{CO}_{2}$ by flowering and nonflowering glumes of the wheat ear and the pattern of transport of label to individual grains. Aust $\mathrm{J}$ Biol Sci 25:921-930

Buerkert A, Oryakhail M, Filatenko AA, Hammer K (2006) Cultivation and taxonomic classification of wheat landraces in the upper Panjsher Valley of Afghanistan after 23 years of war. Genet Resour Crop Evol 53(1):91-97
Croston RP, Williams JT (eds) (1991) A world survey of wheat genetic resources. IBPGR, FAO, Rome

Dorofeev VF, Filatenko AA, Migushova EF, Udacin RA, Jakubziner RR (1979) Wheat. Vol 1. In: Dorofeev VF, Koroviana ON (eds) Flora of cultivated plants. Kolos, Leningrad, Russia, 346 pp

Dotlacil L, Gregova E, Hermuth J, Stehno Z, Kraic J (2002) Diversity of HMW-Glu alleles and evaluation of their effects on some characters in winter wheat landraces and old cultivars. Czech J Genet Plant Breed 38(3-4):109-116

Feldman M (2001) Origin of cultivated wheat. In: Bonjean AP, Angus WJ (eds) The world wheat book. A history of wheat breeding. Lavoisier Publishing, Paris, pp 3-57

Ferrão JEM (1992) A Aventura das Plantas e os Descobrimentos Portugueses. Instituto de Investigação Científica Tropical, Comissão Nacional para as Comemorações dos Descobrimentos Portugueses e Fundação Berardo, Lisboa, $241 \mathrm{pp}$

Ferrio JP, Alonso N, Voltas J, Araus JL (2006) Grain weight changes over time in ancient cereal crops: Potential roles of climate and genetic improvement. J Cereal Sci 44: 323-332

Flaksburger CA (1935) Cereals: Wheat. In: Wulf EV (ed) Flora of cultivated plants I. Cos Izd Kolkh Sovkh. Moscow and Leningrad (St. Petersburg), USSR

Flaksberger CA (1939) Key to true cereals Acad Sci Int Plant Cult. Leningrado, USSR

Gadea M (1954) Trigos Españoles. Instituto Nacional de Investigaciones Agronómicas, Madrid, $150 \mathrm{pp}$

Hammer K, Laghetti G (2005) Genetic erosion-examples from Italy. Genet Resour Crop Evol 52:619-628

IPGRI (1985) Revised descriptor list for wheat (Triticum spp.). IBPGR Secretariat Rome and CEC Secretariat, Brussels

Kinnear PR, Gray CD (1999) SPSS for Windows made simple. Psychology Press, East Sussex

Kovach WL (1999) MVSP_a multivariate statistical package for Windows, ver. 3.1. Kovach Computing Services, Pentraeth, Wales, UK

Mansfeld R (1951) Das morphologische System des Saatweizens, Triticum aestivum L. s.1. Züchter 21:41-60

McFadden ES, Sears ER (1946) The origin of Triticum spelta and its free-threshing hexaploid relatives. J Hered 37: 81-89

Moragues M, Garcia del Moral LF, Moralejo M, Royo C (2006a) Yield formation strategies of durum wheat landraces with distinct pattern of dispersal within the Mediterranean basin I. Yield components. Field Crops Res 95:194-205

Moragues M, Garcia del Moral LF, Moralejo M, Royo C (2006b) Yield formation strategies of durum wheat landraces with distinct pattern of dispersal within the Mediterranean basin II. Biomass production and allocation. Field Crops Res 95:182-193

Olugbemi LB, Austin RB, Bingham J (1976) Effect of awns on the photosynthesis and yield of wheat. Ann Appl Biol 84:241-250

Pinheiro de Carvalho MÂA, Slaski JJ, dos Santos TMM, Ganança JFT, Abreu I, Taylor GJ et al (2003) Identification of aluminium resistant genotypes among Madeiran regional wheats. Commun Soil Sci Plant Anal 34(19-20): 2967-2979 
Pinheiro de Carvalho MÂA, Slaski JJ, Abreu I, Ganança FT, dos Santos TMM, Freitas L et al (2004a) Factors contributing to the development of aluminium tolerance in the Madeiran maize germplasm. J Plant Nutr Soil Sci 167:1-6

Pinheiro de Carvalho MÂA, Wilcock CC, dos Santos TMM, Vale Lucas IC, Ganança JFT, Franco E et al (2004b) A review of the genus Semele (Ruscacae) systematics in Madeira. Bot J Linn Soc 146(4):483-497

Pinheiro de Carvalho MÂA, Ganança JFT, Abreu I, Sousa NF, dos Santos TMM, Vieira Clemente RM et al (2008) Evaluation of the maize (Zea mays L.) diversity on the Archipelago of Madeira. Genet Resour Crop Evol 55: 221-233

Silva AF, Meneses CA (1984) Elucidário madeirense, vol 2. SRTC-DRAC, Funchal, p 363

Trethowan RM, Reynolds MP, Skovmand B, van Ginkel M (1998) The effect of glume pubescence on floret temperature in wheat. Agronomy Abstracts 1998. ASA, 18-22 October, Baltimore, MD, p 161
Vasconcellos JC (1933a) Trigos Portugueses ou de há muito cultivados no País (subsídios para o seu estudo botânico). Boletim de Agricultura, Números 1 e 2-I série, 151 pp

Vasconcellos JC (1933b) Alguns trigos estrangeiros cultivados em Portugal, sua descrição botânica. Separata da "Revista Agronómica, Lisboa

Vasconcellos JC (1943) Actualização da Sistemática dos trigos Portugueses, vol XIV. Separata dos anais do Instituto Superior de Agronomia, Lisboa

Vieira A (1983a) O comércio de cereais dos Açores para a Madeira no século XVII. Separata do Boletim do Instituto Histórico da ilha, Terceira, pp 651-676

Vieira A (1983b) O comércio de cereais das Canárias para a Madeira no século XVI-XVII. Separata Del VI colóquio de Historia Canário-Americana, pp 328-351

Zeven AC (1998) Landraces: a review of definitions and classifications. Euphytica 104:127-139

Zohary D, Hopf M (2000) Domestication of plants in the Old World, 3rd edn. Oxford University Press, New York, 316 pp 